\title{
Specify PDGFRA Mutation
}

National Cancer Institute

\section{Source}

National Cancer Institute. Specify PDGFRA Mutation. NCI Thesaurus. Code C160580.

A request to enter the specific PDGFRA mutations that were identified in the study. 